\title{
ANALISIS PENGARUH EKSPOR DAN KONSUMSI BATUBARA TERHADAP PERTUMBUHAN EKONOMI INDONESIA
}

\author{
Analysis of Coal Export and Coal Consumption Effects on \\ Economic Growth in Indonesia
}

\author{
ARIF SETIAWAN, ARYO P. WIBOWO dan FADHILA A. ROSYID \\ Program Studi Rekayasa Pertambangan-Institut Teknologi Bandung \\ Jalan Ganesha 10 Bandung 40132 \\ e-mail: arif_bsp@yahoo.com
}

\begin{abstract}
ABSTRAK
Sebagai salah satu bahan bakar fosil, sebagian besar jumlah produksi batubara Indonesia sampai saat ini diekspor ke berbagai negara yang masih mengandalkan komoditas ini sebagai sumber energi listrik. Namun berdasarkan Peraturan Presiden (Perpres) nomor 22 tahun 2017 tentang Rancangan Umum Energi Nasional (RUEN), produksi batubara akan dibatasi sebesar 400 juta ton per tahun dan akan dilakukan pengurangan ekspor material ini secara bertahap dari tahun ke tahun serta akan dihentikan paling lambat pada 2046 dalam rangka memprioritaskan kebutuhan dalam negeri guna mewujudkan kemandirian dan ketahanan energi mendukung pembangunan nasional berkelanjutan. Oleh karena itu, kebutuhan batubara untuk memenuhi permintaan dalam negeri akan berpengaruh pada ekspor batubara sehingga akan berdampak kepada pertumbuhan ekonomi. Untuk mengetahui pengaruh tersebut, penelitian ini diuji dengan metode Vektor Autoregresi (VAR) menggunakan periode 29 tahun dari 1990 hingga 2018. Hasil pengujian menunjukkan bahwa selama periode tersebut, konsumsi batubara dalam negeri dan ekspor batubara berdampak positif terhadap pertumbuhan ekonomi yang ditunjukkan oleh fakta bahwa setiap kenaikan satu unit satuan variabel ekspor batubara (DLNEB) untuk satu dan dua periode sebelumnya memberikan kenaikan nilai PDB (DLNPDB) yang diperkirakan sebesar 0,125 unit satuan. Selain itu, setiap terjadi kenaikan satu unit satuan pada variabel konsumsi batubara (DLNKB) pada satu dan dua periode sebelumnya dapat memberikan kenaikan pada nilai PDB (DLNPDB) yang diestimasi sebesar 0,195 unit satuan.
\end{abstract}

Kata kunci: batubara, ekspor, konsumsi, pertumbuhan ekonomi.

\begin{abstract}
Most of Indonesia coal production is currently exported to various countries that still rely on coal as a source of electrical energy. However, based on Presidential Regulation (Perpres) number 22 of 2017 concerning the National Energy General Draft (RUEN), coal production will be limited to 400 million tons per year and will reduce coal exports gradually from year to year and will be stopped no later than in 2046 to prioritize the domestic needs in terms of realizing the energy independence and energy security for supporting the sustainable national development. Referring to such the fact, the need of coal to meet the domestic demand will affect the coal exports. This fact will affect the economic growth. To determine the effect, the research will be tested by the Vector Autoregression (VAR) method using a 29-year period, namely from 1990 to 2018. The results show that during 29-year period, the domestic
\end{abstract}


coal consumption and coal exports provide a positive impact on the economic growth. The study shows that for every increase in the coal export variable (DLNEB) within one and two previous periods is able to increase the GDP (DLNPDB) which is estimated at 0.125 unit. In addition, if there is an increase in one unit of the coal consumption variable (DLNKB) within one and two previous periods the increase of GDP (DLNPDB) value is estimated at 0.195 unit.

Keywords: coal, export, consumption, economic growth.

\section{PENDAHULUAN}

Batubara adalah salah satu bahan bakar fosil yang menurut Undang-Undang Nomor 4 Tahun 2009 merupakan endapan senyawa organik yang terbentuk secara alamiah dari sisa tumbuhtumbuhan. Batubara dimanfaatkan di berbagai industri seperti pembangkit tenaga listrik, semen, kertas, baja, dan lainnya. Industri merupakan sektor produktif yang terus didorong perkembangannya agar dapat meningkatkan perekonomian negara. Batubara Indonesia sebagian besar digunakan untuk memenuhi kebutuhan energi Pembangkit Listrik Tenaga Uap (PLTU) dan sektor industri lainnya. Haryadi dan Suciyanti (2018) menjelaskan bahwa seluruh konsumsi batubara dalam negeri pada 2016 sebesar $76 \%$ yang di antaranya digunakan oleh PLTU. Sisanya sebesar $24 \%$ digunakan industri semen, metalurgi, pupuk, kertas, tekstil, dan briket.

Batubara diperlukan untuk memenuhi kebutuhan energi sebagai upaya untuk mengurangi ketergantungan terhadap minyak yang disebabkan cadangannya berkurang. Menurut Yudiartono dkk. (2018), cadangan batubara Indonesia pada 2016 tercatat sebesar $28.457,29$ juta ton yang diperkirakan dapat bertahan kurang lebih 68 tahun lagi. Selain batubara, terdapat sumber energi terbarukan dengan potensi cukup besar, namun sumber energi tersebut masih belum optimal dikembangkan karena berbagai kendala penerapannya, seperti investasi tinggi, efisiensi teknologi relatif rendah, serta letak geografis dan faktor sosial masyarakat pengguna energi. Perkembangan sumber energi terbarukan tidak menunjukkan indikasi bahwa ketergantungan pada bahan bakar fosil akan menurun secara signifikan dalam waktu dekat, maka batubara dapat menjadi salah satu sumber energi di Indonesia.

Alasan kenapa batubara menjadi salah satu sumber energi yang unggul dibandingkan sumber energi lainnya dikarenakan potensi yang dimiliki relatif besar. Hal ini berdasarkan informasi yang diperoleh dari Kementerian Energi dan Sumber Daya Mineral (2018), cadangan minyak dan gas bumi yang dimiliki Indonesia tercatat per 1 Januari 2018 sebesar 7,51 miliar barrel (setara 1.024,4 juta ton) dan 135,55 TSCF (setara $3.087,7$ juta ton). Sedangkan untuk batubara sendiri cadangan yang dimiliki Indonesia tercatat per Desember 2018 sebesar 39.890,95 juta ton. Oleh karena itu produksi batubara pun lebih besar dibandingkan dengan minyak bumi dan gas alam seperti terlihat pada Tabel 1 . Selain itu batubara dapat diolah menjadi energi alternatif pengganti minyak dan gas yang sampai saat ini produksinya cenderung menurun.

Tabel 1. Produksi batubara, minyak dan gas alam.

\begin{tabular}{cccccc}
\hline \multirow{2}{*}{ Tahun } & \multicolumn{2}{c}{ Minyak Bumi } & \multicolumn{2}{c}{ Gas Alam } & Batubara \\
\cline { 2 - 5 } & Ribu Barrel & Juta Ton & MMSCF & Juta ton & Juta ton \\
\hline 2010 & 344.888 & 47,04 & 3.407 .592 & 77,62 & 275,16 \\
2011 & 329.265 & 44,91 & 3.256 .379 & 74,18 & 353,27 \\
2012 & 314.666 & 42,92 & 3.174 .639 & 72,31 & 386,08 \\
2013 & 300.830 & 41,03 & 3.120 .838 & 71,09 & 474,37 \\
2014 & 287.902 & 39,27 & 3.175 .791 & 72,34 & 458,10 \\
2015 & 286.814 & 39,12 & 3.116 .142 & 70,98 & 461,57 \\
2016 & 304.167 & 41,49 & 3.070 .239 & 69,94 & 456,20 \\
2017 & 292.374 & 39,88 & 2.963 .184 & 67,50 & 461,25 \\
2018 & 281.826 & 38,44 & 2.996 .802 & 68,26 & 557,77 \\
\hline
\end{tabular}

Sumber: Kementrian Energi dan Sumber Daya Mineral (2018). 
Walaupun produksi batubara cukup besar, sebagian besar jumlah produksi batubara Indonesia sampai saat ini diekspor ke berbagai negara yang masih mengandalkan batubara sebagai sumber energi listrik. Hal ini dikarenakan Indonesia memiliki posisi geografis yang strategis untuk negara-negara berkembang seperti Cina dan India. Kedua negara tersebut merupakan sekian dari beberapa negara yang mengimpor batubara Indonesia untuk memenuhi kebutuhan energi di negaranya.

Berdasarkan Kementerian Energi dan Sumber Daya Mineral (2016, 2018), pada 2000 hingga 2018 batubara yang diekspor menunjukkan kecenderungan kenaikan dengan porsi yang diekspor rata-rata sekitar $76,4 \%$ dan sisanya digunakan dalam negeri.

Batubara merupakan salah satu komoditas ekspor non migas yang berkontribusi bagi pertumbuhan ekonomi. Putra dan Damanik (2017), menjelaskan bahwa ekspor migas, dan non migas merupakan mesin pertumbuhan ekonomi di Indonesia. Akan tetapi Peraturan Presiden (perpres) nomor 22 Tahun 2017 tentang Rancangan Umum Energi Nasional (RUEN), produksi batubara akan dibatasi sebesar 400 juta ton per tahun dan akan dilakukan pengurangan ekspor batubara secara bertahap dari tahun ke tahun serta akan dihentikan paling lambat pada 2046 dalam rangka memprioritaskan kebutuhan dalam negeri mewujudkan kemandirian dan ketahanan energi mendukung pembangunan nasional berkelanjutan.

Peningkatan kebutuhan batubara dalam negeri tidak lepas dari kebijakan yang dikeluarkan oleh pemerintah yaitu kewajiban bagi produsen batubara untuk memenuhi kebutuhan batubara dalam negeri agar batubara yang diproduksi dalam negeri dapat dimanfaatkan semaksimal mungkin. Kebijakan tersebut termuat dalam UU No. 4 tahun 2009 Pasal 5 terkait pengutamaan mineral dan batubara dalam negeri yaitu kebijakan pengendalian produksi dan ekspor, selain itu pada Pasal 102 dan 103 terkait kewajiban untuk meningkatkan nilai tambah mineral dan batubara (minerba). Pengendalian produksi dan ekspor serta peningkatan nilai tambah minerba lebih lanjut diatur dalam Peraturan Pemerintah (PP) No. 23 Tahun 2010 pada Pasal 84, 91, 92, dan 96. Beberapa pasal dalam PP
No. 23 tahun 2010 lebih lanjut diatur pada Peraturan Menteri (Permen) No. 25 Tahun 2018 Pasal 16, 31, 32, dan 35. Oleh karena itu, kebutuhan batubara untuk memenuhi permintaan dalam negeri akan berpengaruh pada ekspor batubara ke beberapa negara yang membutuhkan sehingga akan berdampak pada pertumbuhan ekonomi.

Berdasarkan Badan Pusat Statistik (2015, 2020), nilai PDB pada 2000 hingga 2018 menunjukkan tren kenaikan. Selain itu menurut Kementerian Energi dan Sumber Daya Mineral $(2016,2018)$, konsumsi batubara dalam negeri dan ekspor batubara pun mengalami kecenderungan kenaikan. Kecenderungan kenaikan ketiga variabel tersebut menunjukkan adanya indikasi hubungan searah yang akan diuji menggunakan pendekatan vektor autoregresi (VAR) sehingga dapat diketahui dampak yang diberikan ekspor batubara dan konsumsi batubara dalam negeri terhadap pertumbuhan ekonomi.

\section{METODE}

Berdasarkan penjelasan sebelumnya, tujuan penelitian ini adalah untuk mengetahui pengaruh ekspor batubara dan konsumsi batubara terhadap pertumbuhan ekonomi. Oleh karena itu penelitian ini tergolong dalam penelitian asosiatif. Menurut Sugiyono (2015), penelitian asosiatif adalah penelitian yang bertujuan untuk mengetahui pengaruh ataupun hubungan antara dua variabel atau lebih. Seperti yang dijelaskan pada pendahuluan bahwa pendekatan atau metode yang akan digunakan dalam penelitian ini adalah VAR yang berfokus pada ekspor dan penggunaan batubara dalam negeri terhadap pertumbuhan ekonomi. Berdasarkan metode penelitian tersebut, berikut ini adalah langkah-langkah yang akan dilakukan yaitu:

1. Mengumpulkan data

Data yang dikumpulkan dan digunakan dalam penelitian ini adalah data sekunder dari 1990-2018 yang berasal dari BPS Indonesia dan content handbook of energi and economic statistics of Indonesia. Data yang akan dikaji, adalah:

1) Konsumsi batubara dalam negeri dalam satuan ton.

2) Ekspor batubara dalam satuan ton.

3) PDB Indonesia dalam satuan milyar rupiah. 
2. Mengolah data

Data yang dikumpulkan dalam penelitian ini adalah data runtut waktu sehingga pengolahan data yang digunakan adalah ekonometrika deret waktu. Ekonometrika deret waktu adalah teknik ekonometrika untuk menganalisis perilaku data deret waktu (Juanda dan Junaidi, 2012). Ekonometrika deret waktu yang digunakan pada penelitian ini adalah vektor autoregresi (VAR). Urutan pengolahan data dapat dilihat pada Gambar 1.

\section{Tinjauan Pertumbuhan Ekonomi}

Pertumbuhan ekonomi mengukur pertambahan pendapatan nasional yang dihitung pada harga konstan atau diukur dari perbedaan Produk Domestik Bruto (PDB) tahun tertentu dengan tahun sebelumnya. PDB diartikan sebagai nilai barang dan jasa yang diproduksi di dalam negara tersebut dalam satu tahun tertentu (Sukirno, 2008). Perekonomian akan mengalami pertumbuhan apabila jumlah total output produksi barang dan penyediaan jasa tahun tertentu lebih besar dari tahun sebelumnya.
Pertumbuhan ekonomi suatu negara sangat membutuhkan adanya ketersediaan sumber daya alam. Sumber daya alam secara umum terbagi atas dua yaitu yang dapat diperbarui dan yang tidak dapat diperbarui. Sumber daya alam yang disebut pertama adalah sumber daya alam yang tersedia terus menerus sebagai input produksi, sedangkan sumber daya yang kedua adalah sumber daya alam yang persediaannya sebagai input produksi sangat terbatas. Contohnya adalah minyak bumi, gas bumi, dan batubara.

Sumber daya alam tersebut dapat dijadikan sebagai sumber energi. Energi merupakan salah satu unsur penting dalam mendukung perekonomian negara. Tanpa energi tidak mungkin menjalankan aktivitas ekonomi seperti mengoperasikan pabrik dan lain sebagainya. Kebutuhan energi untuk pembangkit listrik akan terus meningkat sejalan dengan perkembangan industri. Apabila pertumbuhan ekonomi semakin meningkat ditambah dengan jumlah penduduk yang meningkat, maka konsumsi energi pun semakin bertambah.

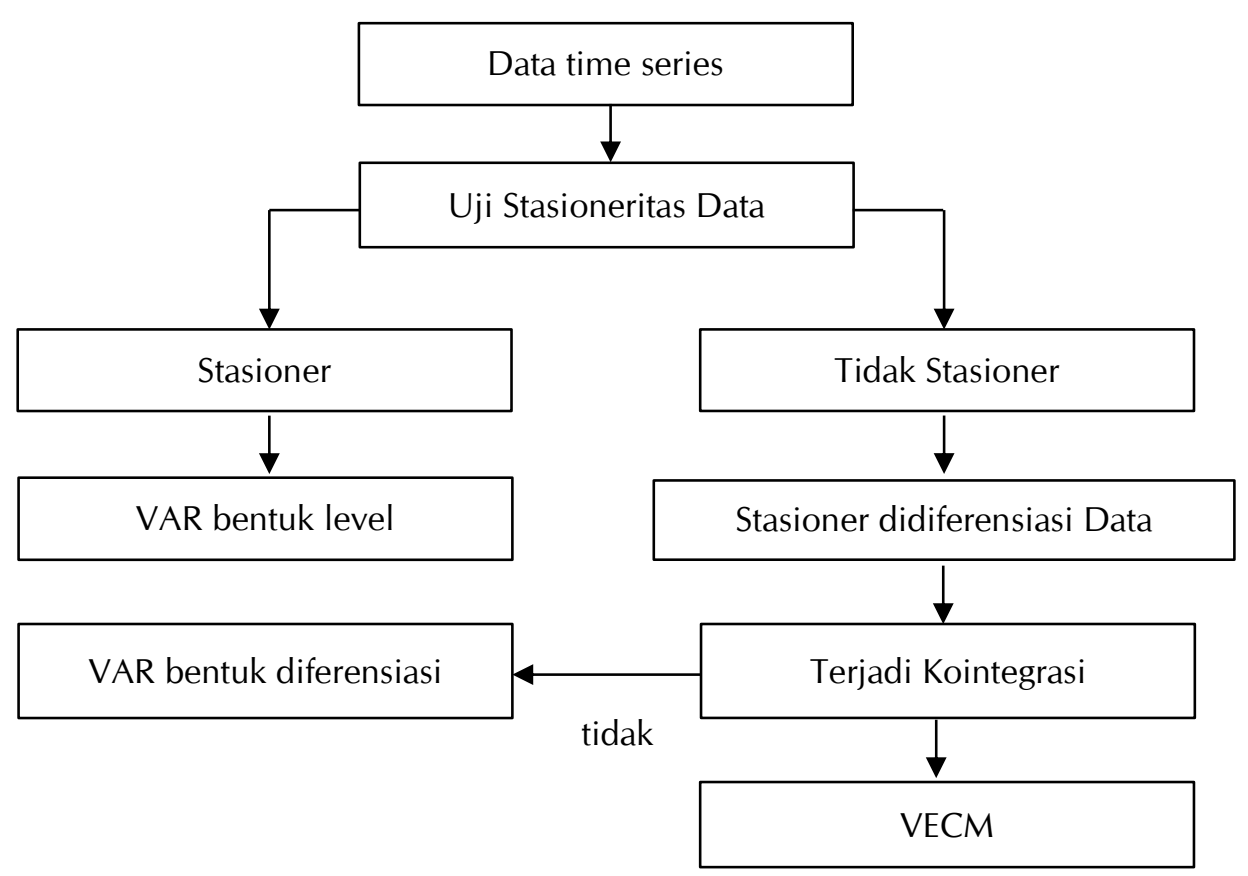

Sumber: Widarjono (2018)

Gambar 1. Proses Pembentukan VAR 
Hubungan antara PDB dengan konsumsi energi telah diteliti secara empiris dan salah satu masalah yang masih diperdebatkan oleh banyak peneliti dikarenakan hasil yang diperoleh bervariasi untuk satu set data yang berbeda bahkan untuk negara yang sama dengan metode yang berbeda. Singkatnya perbedaan tersebut timbul dikarenakan rentan waktu, metode, dan keragaman variabel yang digunakan.

Dari studi empiris yang pernah dilakukan oleh Zahmir (2014) untuk Indonesia dari 1967 sampai 2012 menggunakan metode kausalitas Granger (Granger causality). Hasil studi menunjukkan bahwa terdapat hubungan dua arah yaitu konsumsi energi memiliki hubungan dengan pertumbuhan ekonomi dan pertumbuhan ekonomi memiliki hubungan dengan konsumsi energi. Studi empiris pun dilakukan oleh Faisal, Tursoy dan Ercantan (2017) untuk negara yang berbeda yaitu Belgia. Periode yang digunakan dari 1960 sampai dengan 2012 dengan menerapkan Autoregresi Distribusi Lag (ARDL) yang diikuti metode TodaYamamoto untuk mengidentifikasi kausalitas. Hasil menunjukkan bahwa terdapat hubungan searah dari PDB ke konsumsi energi di Belgia.

Batubara merupakan salah satu sumber energi yang digunakan di berbagai negara yang berperan pada pertumbuhan ekonomi. Dalam penelitian Yoo (2006) yang meneliti masalah kausalitas antara konsumsi batubara dan pertumbuhan ekonomi di Korea dengan metode Granger, digunakan data tahunan yang mencakup periode 1968-2002. Hasil menunjukkan bahwa ada dua arah kausalitas berjalan dari konsumsi batubara ke pertumbuhan ekonomi dengan umpan balik. Hal ini berarti bahwa peningkatan konsumsi batubara secara langsung memengaruhi pertumbuhan ekonomi. Dengan demikian, agar tidak memengaruhi pertumbuhan ekonomi, Korea harus berusaha untuk mengatasi kendala pada konsumsi batubara.

Li dan Li (2011), melakukan penelitian untuk Cina dan India. Dua negara ini merupakan negara dengan pertumbuhan ekonomi terkuat di dunia. Kedua negara banyak mengonsumsi batubara untuk mendorong pertumbuhan ekonomi. Dalam penelitian ini metode yang digunakan adalah kausalitas Granger untuk menguji hubungan antara konsumsi batubara dan PDB di Cina dan India. Data untuk penelitian ini dari 1965 hingga 2006. Hasil yang diperoleh menunjukkan bahwa di Cina terdapat kausalitas searah dari PDB ke konsumsi batubara. Sedangkan di India hubungan yang terjadi sebaliknya yaitu kausalitas searah dari konsumsi batubara ke PDB.

Kim dan Yoo (2016) melakukan pengujian hubungan sebab akibat antara konsumsi batubara dengan pertumbuhan ekonomi di Indonesia untuk periode 1965-2010. Hasil estimasi menunjukkan bahwa terdapat hubungan (kausalitas) dua arah dari konsumsi batubara ke pertumbuhan ekonomi di Indonesia. Hubungan tersebut menyiratkan bahwa peningkatan konsumsi batubara secara langsung merangsang pertumbuhan ekonomi.

Korra (2017) dalam penelitiannya menjelaskan bahwa berdasarkan uji kausalitas Granger hubungan kausalitas antara konsumsi batubara dengan PDB bersifat satu arah (unidirectional) yaitu dari konsumsi batubara ke PDB. Hal ini dikarenakan batubara di Indonesia paling banyak dikonsumsi untuk sektor listrik dan industri. Listrik merupakan bentuk energi yang sangat penting sebagai salah satu input produksi, sehingga pasokan yang memadai dapat mendukung kegiatan ekonomi agar dapat berjalan dengan baik. Sama halnya dengan peningkatan batubara yang dikonsumsi oleh sektor industri menunjukkan meningkatnya aktivitas industri. Peningkatan tersebut dapat memberikan input positif bagi nilai PDB.

Penelitian serupa dilakukan untuk melihat hubungan antara konsumsi batubara dan pertumbuhan ekonomi di negara yang berbeda dan hasilnya dapat bervariasi seperti yang dilakukan oleh Chang $d k k$. (2017) yang menganalisis hubungan sebab akibat antara konsumsi batubara dan pertumbuhan ekonomi di negara-negara BRICS (Brasil, Rusia, India, Cina, dan Afrika Selatan) menggunakan data tahunan dari 1985 hingga 2009. Hasil yang diperoleh menjelaskan bahwa dari kelima negara tersebut memperoleh hasil yang berbeda-beda. Untuk Brazil, Rusia, dan Afrika Selatan ditemukan tidak terdapat hubungan sebab akibat antara konsumsi batubara dan pertumbuhan ekonomi. Sebaliknya untuk Cina, hasil yang didapatkan menunjukkan adanya hubungan searah dari konsumsi batubara ke pertumbuhan ekonomi. Lain halnya dengan India, hasil yang diperoleh menunjukkan 
terdapat hubungan dua arah antara konsumsi batubara dengan pertumbuhan ekonomi. Jadi untuk Cina dan India, upaya untuk mengurangi penggunaan batubara sebagai sumber energi berpotensi membahayakan pertumbuhan ekonomi.

\section{Ekspor Batubara}

Suatu negara melakukan ekspor suatu produk ke negara lain yang membutuhkan dikarenakan setiap negara memiliki karakteristik sumber daya alam yang berbeda atau di dalam negerinya memiliki komoditas yang melimpah/ berlebih dan negara yang mengimpor tidak dapat memenuhi barang tersebut.

Ekspor merupakan salah satu indikator dalam memacu pertumbuhan ekonomi suatu negara. Seperti yang dikemukakan oleh Arianti, Siahaan dan Sihaloho (2017), bahwa pertumbuhan ekonomi dipengaruhi oleh berbagai faktor yang salah satunya adalah ekspor. Menurut Salvator dalam Ginting (2017), menjelaskan bahwa ekspor merupakan salah satu mesin pendorong pertumbuhan ekonomi. Jung dan Marshall dalam Ginting (2017), mengemukakan bahwa terdapat empat hipotesis hubungan antara ekspor dengan pertumbuhan ekonomi yaitu:

1. Ekspor sebagai penggerak pertumbuhan ekonomi suatu negara (export-led growth);

2. Ekspor menjadi penyebab menurunnya pertumbuhan ekonomi suatu negara (export-reduced growth);

3. Pertumbuhan ekonomi yang menjadi pendorong ekspor suatu negara (internally generated export);

4. Pertumbuhan ekonomi menyebabkan turunnya ekspor dari negara tersebut.

Penelitian yang dilakukan oleh Putra dan Damanik (2017), menjelaskan bahwa Indonesia memiliki mesin pertumbuhan ekonomi dari ekspor migas dan non migas. Sektor non migas itu sendiri terdiri dari sektor pertanian, industri, tambang serta sektor lainnya. Untuk sektor pertambangan yang paling dominan adalah batubara dibandingkan dengan hasil tambang lainnya.

Sinaga, Rochaid dan Ulfah (2013) mempelajari pengaruh ekspor batubara terhadap pertumbuhan ekonomi di Kalimantan Timur. Hasil analisis menunjukkan bahwa ekspor sektor pertambangan dalam hal ini batubara berpengaruh positif terhadap pertumbuhan ekonomi di Kalimantan Timur.

Penelitian selanjutnya dilakukan Dewi (2018) yang menganalisis ekspor batubara di Indonesia. Variabel yang digunakan adalah variabel PDB negara tujuan ekspor, harga batubara, dan nilai tukar. Data yang digunakan adalah data dari 2010-2015, sedangkan metode yang digunakan adalah analisis regresi data panel. Hasilnya menunjukkan bahwa PDB total negara tujuan berpengaruh positif terhadap ekspor batubara Indonesia sehingga dapat dikatakan bahwa PDB negara tujuan merupakan salah satu pengaruh positif untuk ekspor batubara Indonesia.

\section{Konsumsi Batubara Indonesia}

Melihat konsumsi batubara yang cenderung meningkat, produksi batubara nasional akan terus meningkat dikarenakan batubara masih merupakan jenis bahan bakar fosil murah dan sangat diperlukan untuk memenuhi kebutuhan PLTU dan beberapa industri seperti semen, baja, dan industri lainnya. Konsumsi batubara domestik didominasi oleh sektor pembangkit listrik (PLTU) rata-rata sebesar $61 \%$ dari konsumsi batubara nasional (Direktorat Sumber Daya Energi Mineral dan Pertambangan BAPPENAS, 2016). Dominasi selanjutnya adalah industri semen - rata-rata sebesar $13 \%$ serta diikuti industri lainnya. Jika dibandingkan antara nilai ekspor dan konsumsi batubara (Tabel 2), nilai persentase ekspor sekitar 80,69 persen lebih besar dibandingkan pemenuhan dalam negeri.

Dasar pemenuhan kebutuhan batubara dalam negeri ini didukung oleh regulasi/peraturan yang dikeluarkan pemerintah yaitu:

1. Pada 2006, peranan batubara di dalam negeri semakin penting sejak dikeluarkannya Peraturan Presiden Nomor 71 Tahun 2006 mengenai penugasan kepada PT. Perusahaan Listrik Negara (persero) untuk melakukan percepatan pembangunan pembangkit listrik yang menggunakan batubara untuk mempercepat diversifikasi energi pembangkit listrik ke bahan bakar non minyak dalam rangka pemenuhan kebutuhan tenaga listrik. 
Tabel 2. Perbandingan nilai ekspor dan konsumsi batubara dalam negeri

\begin{tabular}{ccccc}
\hline Tahun & Ekspor Batubara (ton) & Konsumsi Batubara (ton) & \% Ekspor & \% Konsumsi dalam negeri \\
\hline 2000 & 58.460 .492 & 18.554 .464 & 75,9 & 24,1 \\
2001 & 65.281 .086 & 27.218 .567 & 70,6 & 29,4 \\
2002 & 74.177 .926 & 29.108 .477 & 71,8 & 28,2 \\
2003 & 85.680 .621 & 28.593 .427 & 75,0 & 25,0 \\
2004 & 93.758 .806 & 38.593 .219 & 70,8 & 29,2 \\
2005 & 110.789 .700 & 41.932 .738 & 72,5 & 27,5 \\
2006 & 143.632 .865 & 50.128 .446 & 74,1 & 25,9 \\
2007 & 163.000 .000 & 53.946 .699 & 75,1 & 24,9 \\
2008 & 191.430 .218 & 48.819 .750 & 79,7 & 20,3 \\
2009 & 198.366 .000 & 57.815 .000 & 77,4 & 22,6 \\
2010 & 208.000 .000 & 67.164 .196 & 75,6 & 24,4 \\
2011 & 272.671 .351 & 80.599 .586 & 77,2 & 22,8 \\
2012 & 304.051 .216 & 82.026 .141 & 78,8 & 21,2 \\
2013 & 356.357 .973 & 72.070 .000 & 83,2 & 16,8 \\
2014 & 381.972 .830 & 76.180 .001 & 83,4 & 16,6 \\
2015 & 365.849 .610 & 86.814 .099 & 80,8 & 19,2 \\
2016 & 331.128 .438 & 90.550 .000 & 78,5 & 21,5 \\
2017 & 297.741 .135 & 97.030 .000 & 75,4 & 24,6 \\
2018 & 356.394 .687 & 115.080 .000 & 75,6 & 24,4 \\
\hline & Rata-rata & & 76,4 & 23,6 \\
\hline
\end{tabular}

Sumber : Kementerian Energi dan Sumber Daya Mineral $(2016,2018)$

2. UU No.30 Tahun 2007 tentang Energi yang termuat pada Pasal 3 terkait tujuan pengelolaan energi adalah penyediaan sumber energi dari dalam negeri untuk memenuhi kebutuhan energi dalam negeri dan Pasal 21 yaitu pemanfaatan energi dilakukan di antaranya dengan mengoptimalkan seluruh potensi sumber daya energi, dan memprioritaskan pemenuhan kebutuhan masyarakat.

3. UU No. 4 Tahun 2009 tentang pertambangan mineral dan batubara, yang termuat pada pasal 3 bagian $\mathrm{C}$ yaitu menjamin tersedianya mineral dan batubara sebagai bahan baku dan/atau sebagai sumber energi untuk kepentingan dalam negeri. Pada Pasal 5 ayat 1 yaitu untuk kepentingan nasional, pemerintah dapat menetapkan kebijakan pengutamaan mineral dan atau batubara untuk kepentingan dalam negeri.

\section{Vektor Autoregresi (VAR)}

VAR adalah sebuah pemodelan persamaan yang di dalamnya mempertimbangkan beberapa variabel endogen (variabel terikat atau tidak bebas) secara bersama-sama dalam model dan setiap variabel dijelaskan oleh nilai lag. Maksudnya adalah dalam memperkirakan variabel dependen diperlukan variabel dependen itu sendiri dan variabel independen.
Semua variabel yang digunakan dalam analisis berhak menjadi variabel dependen dan independen. Kelebihan model ini adalah membuat model statis menjadi dinamis. Model regresi biasanya mengabaikan atau kurang memperhatikan pengaruh waktu, maka melalui model ini waktu akan ikut diperhitungkan. VAR merupakan alat analisis yang baik dan berguna di dalam memahami adanya hubungan timbal balik antara variabelvariabel ekonomi, dikarenakan model-model ekonometrika pada umumnya dibangun berdasarkan hubungan antar variabel yang mengacu kepada teori, namun model VAR tidak dibangun berlandaskan teori. Model VAR memiliki tiga bentuk persamaan seperti yang terlihat pada Gambar 1 yaitu:

1. VAR in level.

Menurut Juanda dan Junaidi (2012), VAR in level adalah salah satu model VAR yang digunakan apabila setelah melakukan uji stasioner hasilnya menunjukkan bahwa masing-masing variabel yang akan diteliti telah stasioner di level. Persamaan model VAR in level adalah:

$\mathrm{Yt}=\mathrm{A}_{0}+\mathrm{A}_{1} \mathrm{Y}_{\mathrm{t}-1}+\mathrm{A}_{2} \mathrm{Y}_{\mathrm{t}-2}+\ldots+\mathrm{A}_{\mathrm{n}} \mathrm{Y}_{\mathrm{t}-\mathrm{p}}+\mathrm{e}_{\mathrm{t}} \ldots$ (1) keterangan:

Ao : Konstanta vector berukuran Mx1 


\begin{tabular}{|c|c|}
\hline $\mathrm{A}_{1,2, \ldots, \mathrm{n}}$ & $\begin{array}{l}\text { : Koefisien vector berukuran } M \\
\times M\end{array}$ \\
\hline$M$ & $\begin{array}{l}\text { : Banyaknya peubah yang } \\
\text { diamati/banyaknya variabel } \\
\text { yang diamati }\end{array}$ \\
\hline $\mathrm{t}$ & $\begin{array}{l}\text { : Banyaknya observasi dengan } \\
\text { lag } p\end{array}$ \\
\hline$Y_{t}$ & $\begin{array}{l}\text { Vektor variabel dependen (tak } \\
\text { bebas) yang diamati. }\end{array}$ \\
\hline$Y_{t-1, t-2, \ldots, t-p}$ & $\begin{array}{l}\text { Vektor variabel yang diamati } \\
\text { tahun sebelumnya }\end{array}$ \\
\hline & : Kesalahan (error) \\
\hline
\end{tabular}

2. $V A R$ in difference

VAR in difference adalah salah satu model VAR yang digunakan apabila setelah melakukan uji stasioneritas hasilnya tidak stasioner di level, tetapi stasioner di diferensiasi tingkat pertama dan seterusnya. Difference disimbolkan dengan $\Delta$ yang artinya selisih dari nilai saat ini yang dikurangi dengan nilai dari tahun yang lalu (tahun sebelumnya).

$\Delta \mathrm{Yt}=\mathrm{Y}_{\mathrm{t}}-\mathrm{Y}_{\mathrm{t}-1}$

Keterangan:

$\Delta$ : tingkat diferensiasi

Dari Persamaan 2, diperoleh model VAR berikut.

$\Delta \mathrm{Yt}=\mathrm{A}_{0}+\mathrm{A}_{1} \Delta \mathrm{Y}_{\mathrm{t}-1}+\ldots+\mathrm{A}_{\mathrm{n}} \Delta \mathrm{Y}_{\mathrm{t}-\mathrm{p}}+\mathrm{et}_{\mathrm{t}}$

3. Vektor Error Corection Model (VECM)

VECM adalah model VAR yang digunakan apabila variabel yang telah diuji stasioneritas hasilnya menunjukkan tidak stasioner di level tetapi setelah melakukan uji kointegrasi yaitu dengan kombinasi linear dari beberapa variabel pengamatan yang hasilnya menunjukkan terdapat hubungan kointegrasi. Error corection model (ECM) adalah kombinasi linear dari peubah $\Delta \mathrm{Y}_{\mathrm{t}-1}$ yang berguna dalam memperkirakan efek jangka pendek dan jangka panjang dari suatu rangkaian waktu.
Persamaan model ini adalah sebagai berikut.

$\begin{aligned} \Delta \mathrm{Yt}= & \mathrm{A}_{0}+\mathrm{A}_{1} \Delta \mathrm{Y}_{\mathrm{t}-1}+\ldots+\mathrm{A}_{n} \Delta \mathrm{Y}_{\mathrm{t}-\mathrm{p}}+\mathrm{B}_{1} \mathrm{ECM}_{\mathrm{t}-1} \\ & +\mathrm{e}_{t} \ldots \ldots \ldots \ldots \ldots \ldots \ldots \ldots \ldots \ldots \ldots \ldots \ldots \ldots \ldots \ldots \ldots \ldots \ldots \ldots \ldots \ldots \ldots \ldots\end{aligned}$

Keterangan:

$\mathrm{B}_{1}$ : koefisien ECM dari vektor berukuran MxM.

Untuk mengetahui nilai masing-masing parameter $A_{1}, A_{2}$, dan seterusnya dapat menggunakan persamaan matriks inverse dan perkalian matriks seperti pada Persamaan 5 berikut ini.

C. $A=D$

$\mathrm{A}=\mathrm{C}^{-1} \mathrm{D}$

Keterangan:

Nilai C dapat ditentukan dengan matriks seperti yang terlihat berikut ini.
$A=\left|\begin{array}{c}A_{0} \\ A_{1} \\ A_{2} \\ \cdots \\ A_{n}\end{array}\right|$
$D=\left|\begin{array}{c}\Sigma Y \\ \Sigma Y X_{1} \\ \Sigma Y X_{2} \\ \cdots \\ \Sigma Y X_{n}\end{array}\right|$
$C=\left|\begin{array}{ccccc}\mathrm{n} & \Sigma \mathrm{X}_{1} & \Sigma \mathrm{X}_{2} & \ldots & \Sigma \mathrm{X}_{\mathrm{n}} \\ \Sigma \mathrm{X}_{1} & \Sigma \mathrm{X}_{1}{ }^{2} & \Sigma \mathrm{X}_{1} \mathrm{X}_{2} & \ldots & \Sigma \mathrm{X}_{\mathrm{n}} \mathrm{X}_{\mathrm{n}+1} \\ \Sigma \mathrm{X}_{2} & \Sigma \mathrm{X}_{1} \mathrm{X}_{2} & \Sigma \mathrm{X}_{2}{ }^{2} & \ldots & \ldots \\ \ldots & \ldots & \ldots & \ldots & \ldots \\ \Sigma \mathrm{X}_{\mathrm{n}} & \Sigma \mathrm{X}_{\mathrm{n}} \mathrm{X}_{\mathrm{n}+1} & \ldots & \ldots & \Sigma \mathrm{X}_{n}{ }^{2}\end{array}\right|$
Untuk memudahkan perhitungan Persamaan 5, maka dapat dibuat tabel pembantu (Tabel 3) yang berisi variabel- variabel yang akan dihitung menjadi parameter-parameter A0, A1, A2, dan seterusnya.

Tabel 3. Tabel bantu untuk penentuan nilai parameter/koefisien model VAR

\begin{tabular}{|c|c|c|c|c|c|c|c|c|c|c|c|c|}
\hline No & $\mathrm{Y}$ & $\mathrm{X}_{1}$ & $X_{2}$ & $X_{n}$ & $\mathrm{X}_{1}{ }^{2}$ & $\mathrm{X}_{2}{ }^{2}$ & $X_{n}{ }^{2}$ & $\mathrm{X}_{1} \mathrm{X}_{2}$ & $X_{n} X_{n+1}$ & $\mathrm{YX}_{1}$ & $\mathrm{YX}_{2}$ & $Y X_{n}$ \\
\hline 1 & $\ldots$ & $\ldots$ & $\ldots$ & $\ldots$ & $\ldots$ & $\ldots$ & $\ldots$ & $\ldots$ & $\ldots$ & $\ldots$ & $\ldots$ & $\ldots$ \\
\hline 2 & $\ldots$ & $\ldots$ & $\ldots$ & $\ldots$ & $\ldots$ & $\ldots$ & $\ldots$ & $\ldots$ & $\ldots$ & $\ldots$ & $\ldots$ & $\ldots$ \\
\hline 3 & $\ldots$ & $\ldots$ & $\ldots$ & $\ldots$ & $\ldots$ & $\ldots$ & $\ldots$ & $\ldots$ & $\ldots$ & $\ldots$ & $\ldots$ & $\ldots$ \\
\hline$\ldots$ & $\ldots$ & $\ldots$ & $\ldots$ & $\ldots$ & $\ldots$ & $\ldots$ & $\ldots$ & $\ldots$ & $\ldots$ & $\ldots$ & $\ldots$ & $\ldots$ \\
\hline $\mathrm{n}$ & $\Sigma Y$ & $\Sigma X_{1}$ & $\Sigma X_{2}$ & $\Sigma X_{n}$ & $\Sigma X_{1}^{2}$ & $\Sigma \mathrm{X}_{2}{ }^{2}$ & $\Sigma X_{n}^{2}$ & $\Sigma X_{1} X_{2}$ & $\Sigma X_{n} X_{n+1}$ & $\Sigma Y X_{1}$ & $\Sigma Y_{2}$ & $\Sigma Y X_{n}$ \\
\hline
\end{tabular}


Untuk melakukan analisis VAR, data variabel pengamatan yang digunakan harus stasioner. Oleh sebab itu prosedur dalam pengolahan data menggunakan metode VAR adalah:

1. Uji Stasioner.

Juanda dan Junaidi (2012) mengemukakan bahwa data yang dimasukkan sebagai model VAR harus data yang stasioner. Untuk menduga apakah data yang digunakan stasioner atau tidak, dalam penelitian ini uji stasioner yang digunakan adalah Dickey-Fuller (DF). Untuk mengetahui data yang dikumpulkan stasioner atau tidak dengan cara membandingkan hasil uji ADF dengan nilai kritis Mackinnon. Jika hasil uji ADF lebih kecil dibandingkan dengan nilai kritis Mackinnon maka hal tersebut menjelaskan bahwa data yang dikumpulkan stasioner. Jika sebaliknya maka data tersebut tidak stasioner.

2. Uji Kointegrasi.

Jika data tidak stasioner di level, ada dua kemungkinan model yang dapat digunakan yaitu:

1) Melakukan diferensiasi terhadap data, sehingga data menjadi stasioner dan modelnya menjadi VAR in Difference;

2) Tidak melakukan diferensiasi terhadap data, melainkan merestriksi dengan persamaan kointegrasi sehingga model yang digunakan adalah VECM.

Uji kointegrasi merupakan pengujian lanjutan uji stasioneritas. Bila data variabel yang digunakan tidak stasioner pada level, dapat diduga bahwa kombinasi linear antara variabel tersebut berada dalam kondisi stasioner. Kombinasi linear tersebut dinyatakan dalam error term $\left(\mathrm{e}_{\mathrm{t}}\right)$.

Untuk mengetahui ada tidaknya hubungan kointegrasi pada ketiga variabel tersebut yaitu dengan melalui uji trace statistik. Hasil dari uji tersebut dibandingkan dengan nilai kritis. Bila hasil trace statistik lebih besar dari nilai kritis, hal tersebut mengindikasikan bahwa variabel-variabel tersebut terdapat hubungan kointegrasi. Jika sebaliknya, variabel-variabel tersebut tidak terdapat hubungan kointegrasi.
3. Estimasi VAR.

Estimasi VAR dibentuk setelah uji stasioner untuk VAR dilevel dan atau uji kointegrasi untuk VAR di tingkat diferensiasi maupun VECM. Untuk menentukan koefisienkoefisien pada persamaan VAR dilakukan menggunakan persamaan ordinary least squares (OLS) yaitu Persamaan 5. OLS adalah metode untuk menemukan garis paling pas (the best fit line) sekumpulan titik observasi.

4. Pemilihan Model Terbaik.

Dalam VAR untuk memilih model terbaik dapat dilakukan menggunakan metode Akaike information criteria (AIC) dan Schwarz information criterion (SIC). Model terbaik adalah model yang memiliki nilai AIC dan SIC terkecil.

Selain kedua metode tersebut pemilihan model terbaik dapat dilihat dengan nilai adjusted $\mathrm{R}^{2} / \mathrm{R}^{2}$ terkoreksi. Adjusted $\mathrm{R}^{2}$ adalah nilai $\mathrm{R}^{2}$ yang telah dikoreksi dengan memperhatikan jumlah parameter dalam model.

Setelah mengetahui model terbaik, selanjutnya adalah uji $F$ dan t. Uji F ini dikenal dengan pengujian hipotesis serentak. Pengujian hipotesis serentak merupakan pengujian hipotesis koefisien regresi berganda $A_{1}, A_{2}$, dan $A_{n}$ secara serentak atau bersama-sama mempengaruhi Y. Uji t adalah uji parsial untuk melihat pengaruh masing-masing variabel independen $(\mathrm{X})$ berpengaruh nyata atau tidak secara parsial terhadap variabel dependen $(\mathrm{Y})$.

\section{HASIL DAN PEMBAHASAN}

Data yang dikumpulkan pada penelitian ini memiliki pola yang tidak linear (Gambar 2, 4, dan 6). Oleh karena itu sebelum membangun model data terlebih dahulu dilakukan transformasi menjadi bentuk logaritma natural. Hasil dari transformasi tersebut dapat dilihat pada Gambar 3, 5, dan 7. 


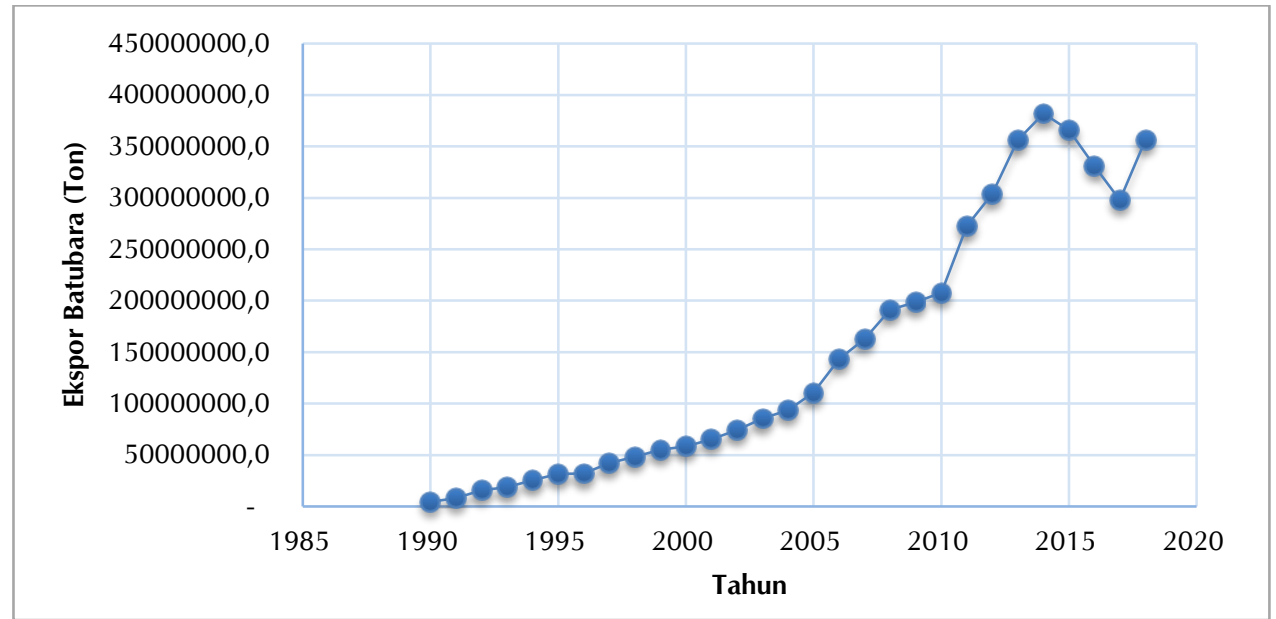

Gambar 2. Pola pergerakan data untuk ekspor batubara pada 1990-2018

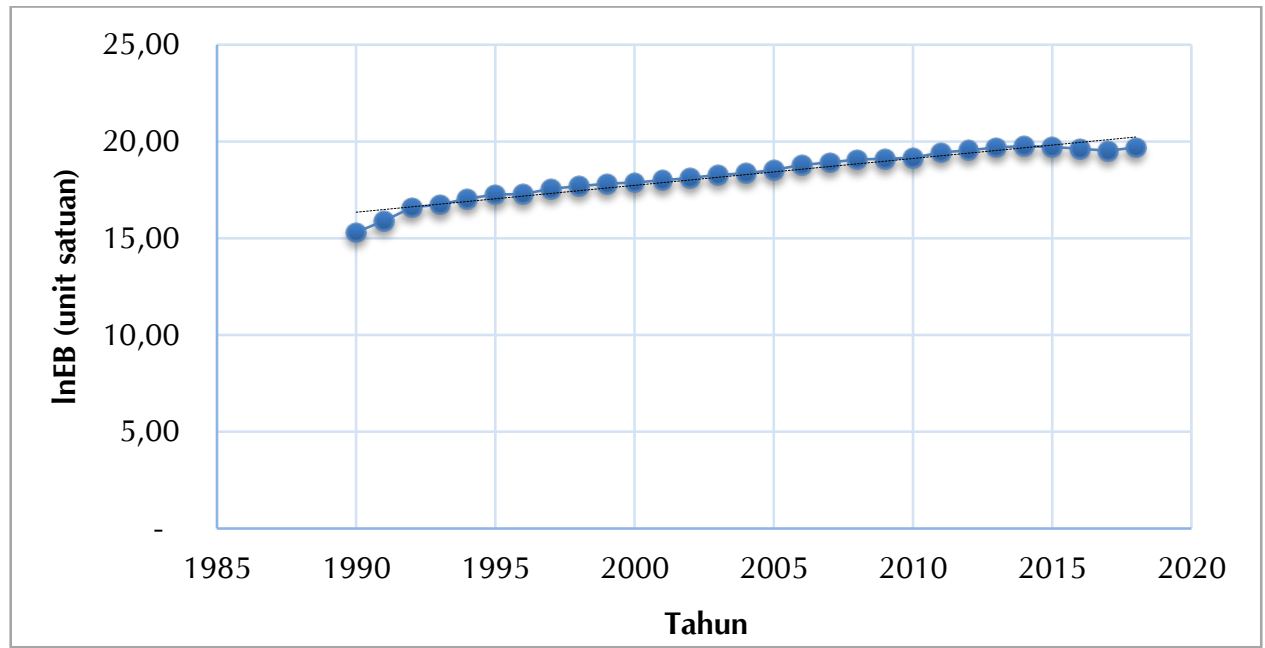

Gambar 3. Pola pergerakan data transformasi (In) ekspor batubara pada 1990-2018

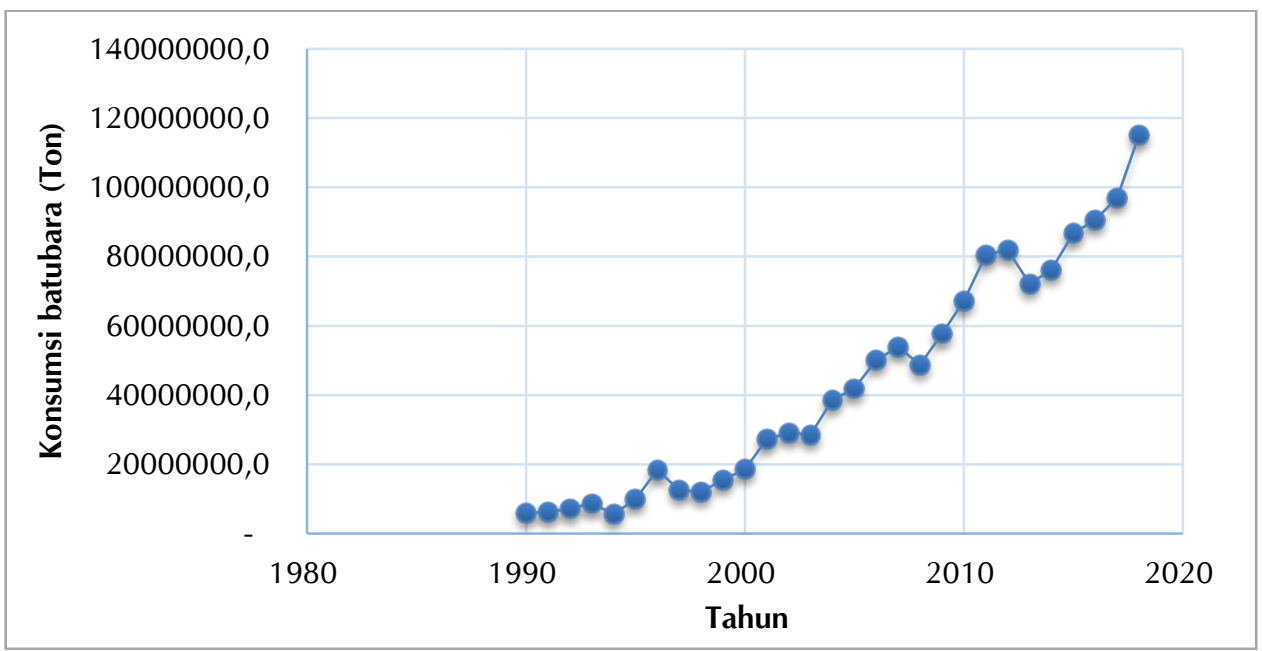

Gambar 4. Pola pergerakan data untuk konsumsi batubara pada 1990-2018 


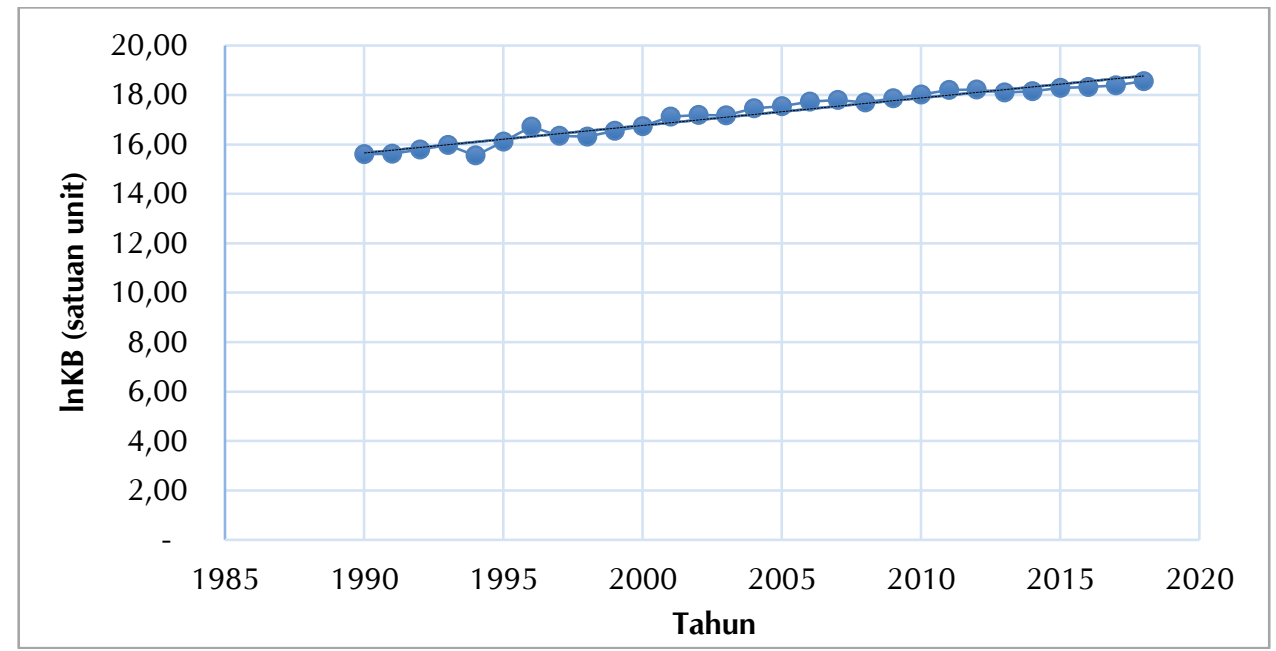

Gambar 5. Pola pergerakan data transformasi (In) konsumsi batubara pada 1990-2018

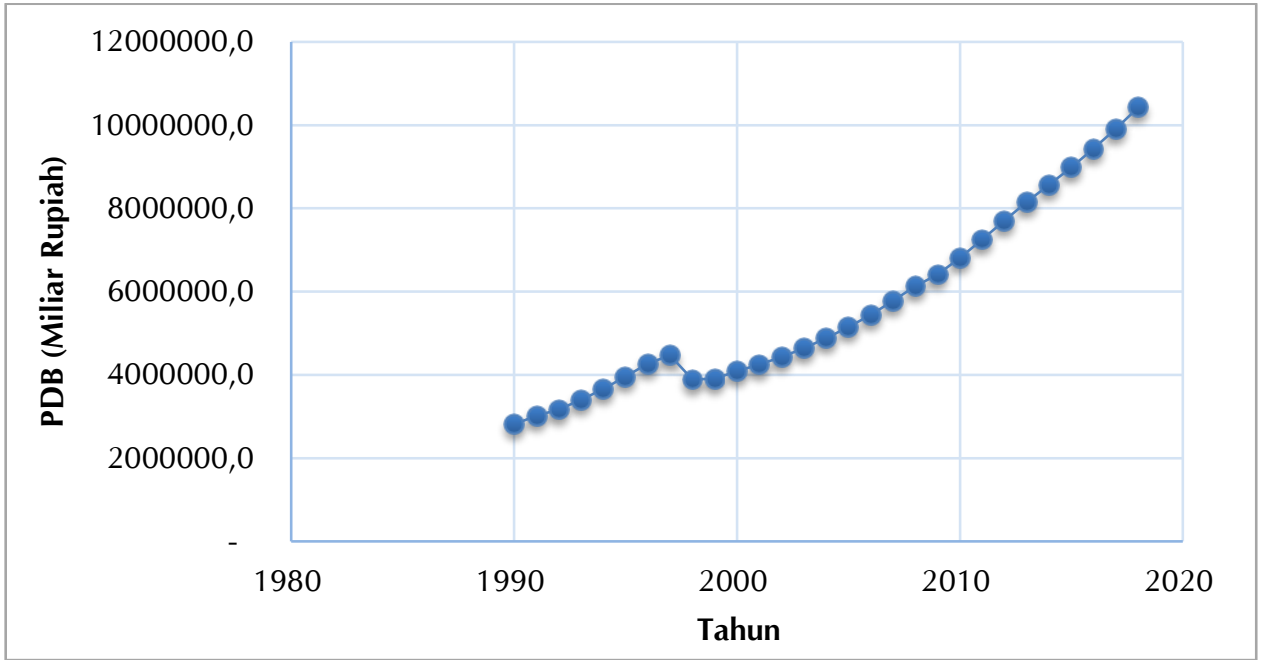

Gambar 6. Pola pergerakan data untuk PDB pada 1990-2018

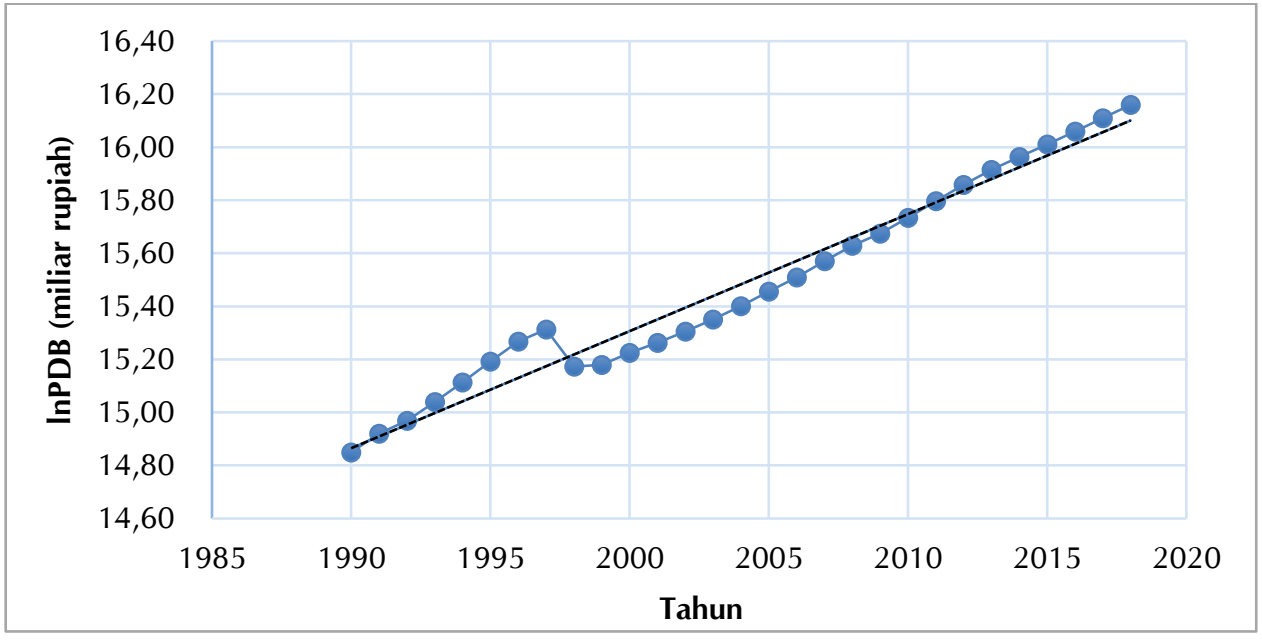

Gambar 7. Pola pergerakan data untuk transformasi (In) PDB pada 1990-2018 
Gambar 3, 5, dan 7 menunjukkan bahwa nilai rata-rata data deret waktu ketiga variabel tidak konstan dari waktu ke waktu atau tidak stasioner. Oleh karena itu terlebih dahulu dilakukan uji stasioner untuk data yang didapat sebelum dilakukan analisis lebih lanjut.

1. Uji Stasioner.

Untuk melihat stasioner atau tidaknya data yang digunakan, maka dilakukan perbandingan dengan melihat nilai t-statistik untuk masing-masing variabel yang dibandingkan dengan nilai kritis MacKinnon seperti pada Tabel 4. Hasil tersebut menunjukkan bahwa data di tingkat level hanya variabel ekspor batubara yang stasioner. Sedangkan variabel PDB dan konsumsi batubara tidak stasioner. Dikarenakan hanya ekspor batubara yang stasioner, maka data yang tidak stasioner dan yang stasioner pada level tersebut diubah melalui proses diferensiasi yaitu pembedaan/selisih tingkat pertama yang di tandai dengan D. Hasil menunjukkan bahwa nilai t-statistik dari ketiga variabel tersebut lebih kecil dibandingkan dengan nilai kritis MacKinnon, yang artinya bahwa data konsumsi batubara, ekspor batubara dan PDB stasioner pada pembedaan (diferensiasi) tingkat pertama.

2. Uji Kointegrasi.

Diketahui bahwa masing-masing variabel data deret waktu yang telah diuji stasioner menunjukkan dua variabel tidak stasioner di tingkat level, tetapi stasioner di tingkat diferensiasi yang sama yaitu diferensiasi tingkat pertama. Langkah selanjutnya adalah melakukan uji kointegrasi untuk mengetahui apakah terdapat hubungan kointegrasi pada ketiga variabel tersebut atau tidak seperti yang terlihat pada Tabel 5.

Hasil menunjukkan bahwa terdapat hubungan kointegrasi antara variabelvariabel tersebut. Oleh karena itu model yang akan dibangun adalah model VECM.

Tabel 5. Hasil Uji Kointegrasi

\begin{tabular}{ccc}
\hline $\begin{array}{c}\text { Hipotesis Jumlah } \\
\text { Persamaan } \\
\text { Kointegrasi }\end{array}$ & $\begin{array}{c}\text { Trace } \\
\text { Statistik }\end{array}$ & $\begin{array}{c}\text { Nilai Kritis } \\
(5 \%)\end{array}$ \\
\hline Tidak ada * & 55,52958 & 35,01090 \\
Paling banyak 1 & 12,80563 & 18,39771 \\
Paling banyak 2 & 0,440597 & 3,841466 \\
\hline
\end{tabular}

Catatan: $\left({ }^{*}\right)$ artinya terdapat persamaan kointegrasi

3. Estimasi Persamaan VAR.

Estimasi model VAR dilakukan setelah uji stasioner dan atau uji kointegrasi dilakukan. Hasil uji tersebut menunjukkan bahwa model yang dibangun adalah VECM. Hasil model VECM terlihat pada Persamaan 6 dan 7.

Tabel 4. Rangkuman hasil uji ADF pada data level dan pada data di tingkat diferensiasi

\begin{tabular}{|c|c|c|c|}
\hline Variabel & t-statistik & Nilai Kritis MacKinnon (5\%) & Keterangan \\
\hline $\operatorname{lnKB}$ & $-2,884206$ & $-3,580623$ & t-statistik > Nilai Kritis \\
\hline $\ln E B$ & $-4,188052$ & $-3,580623$ & t-statistik $<$ Nilai Kritis \\
\hline $\ln P D B$ & $-1,346011$ & $-3,580623$ & t-statistik $>$ Nilai Kritis \\
\hline $\mathrm{D}(\ln K B)$ & $-6,009907$ & $-3,587527$ & t-statistik $<$ Nilai Kritis \\
\hline $\mathrm{D}(\ln \mathrm{EB})$ & $-4,005510$ & $-3,587527$ & t-statistik $<$ Nilai Kritis \\
\hline $\mathrm{D}(\ln \mathrm{PDB})$ & $-3,777049$ & $-3,587527$ & t-statistik $<$ Nilai Kritis \\
\hline
\end{tabular}

$\begin{aligned} \text { DLNPDB }= & -0,130 *\left(\text { LNPDB }_{\mathrm{t}-1}-0,407 * \text { LNEB }_{\mathrm{t}-1}+0,760 * \mathrm{LNKB}_{\mathrm{t}-1}-0,0745 * \text { Periode }(\mathrm{t})-\right. \\ & \text { 19,981) }+0,360 * \text { DLNPDB }_{\mathrm{t}-1}+0,072 * \text { DLNEB }_{\mathrm{t}-1}+0,130 * \text { DLNKB }_{\mathrm{t}-1}-0,023+ \\ & \text { 0,002*Periode }(\mathrm{t})\end{aligned}$

DLNEB $=0,658 *\left(\right.$ LNPDB $_{\mathrm{t}-1}-0,407 * \mathrm{LNEB}_{\mathrm{t}-1}+0,760 * \mathrm{LNKB}_{\mathrm{t}-1}-0,0745 *$ Periode $(\mathrm{t})$ $19,981)-0,386 *$ DLNPDB $_{\mathrm{t}-1}+0,127 *$ DLNEB $_{\mathrm{t}-1}-0,267 *$ DLNKB $_{\mathrm{t}-1}+0,302-$ $0,009 *$ Periode $(\mathrm{t})$ 

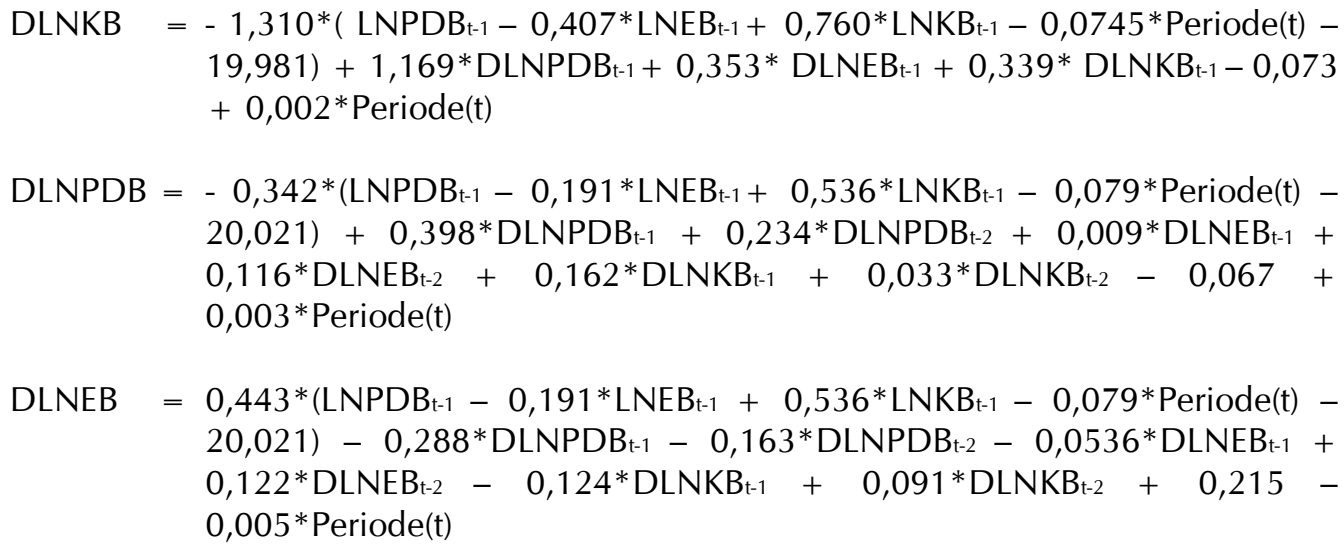

DLNKB $=-1,678 *\left(\right.$ LNPDB $_{\mathrm{t}-1}-0,191 * \mathrm{LNEB}_{\mathrm{t}-1}+0,536 * \mathrm{LNKB}_{\mathrm{t}-1}-0,079 *$ Periode $(\mathrm{t})-$ $20,021)+1,892 *$ DLNPDB $_{\mathrm{t}-1}+1,697 *$ DLNPDB $_{\mathrm{t}-2}+0,371 *$ DLNEB $_{\mathrm{t}-1}-$ $1,062 *$ DLNEB $_{\mathrm{t}-2}+0,316 *$ DLNKB $_{\mathrm{t}-1}-0,434 * \mathrm{DLNKB}_{\mathrm{t}-2}+0,302-$ $0,014 *$ Periode $(\mathrm{t})$

4. Pemilihan Model Terbaik

Pengambilan keputusan untuk memilih model yang baik yaitu dengan melihat nilai AIC atau SIC yang nilainya lebih kecil. Berdasarkan hal tersebut, nilai AIC atau SIC pada Tabel 6 masing-masing model VECM menunjukkan bahwa model VECM dengan lag optimum 2 adalah model yang baik. Model dengan lag optimum 2 tersebut adalah Persamaan 9, 10, dan 11. Berdasarkan tujuan penelitian, model yang dipilih adalah Persamaan 9. Perbandingan hasil model VAR pada Persamaan 9 dan nilai aktual PDB dapat dilihat pada Gambar 8.

Setelah mengetahui bahwa model VECM lag 2 adalah model yang paling baik, selanjutnya adalah uji F. Dari model tersebut nilai $\mathrm{F}$ statistik diperoleh sebesar 3,784506. Apabila nilai tersebut dibandingkan dengan $\mathrm{F}$ tabel sebesar 2,48, maka nilai F statistik lebih besar dari F tabel. Hasil ini menunjukkan bahwa seluruh koefisien yang digunakan atau setidaknya salah satu koefisien dalam model VECM berpengaruh signifikan untuk meramalkan nilai PDB pada tingkat diferensiasi.

Tabel 6. Nilai AIC dan SIC

\begin{tabular}{ccc}
\hline Lag & AIC & SIC \\
\hline 1 & $-5,932305$ & $-4,924432$ \\
2 & $-7,496289$ & $-6,044640$ \\
\hline
\end{tabular}

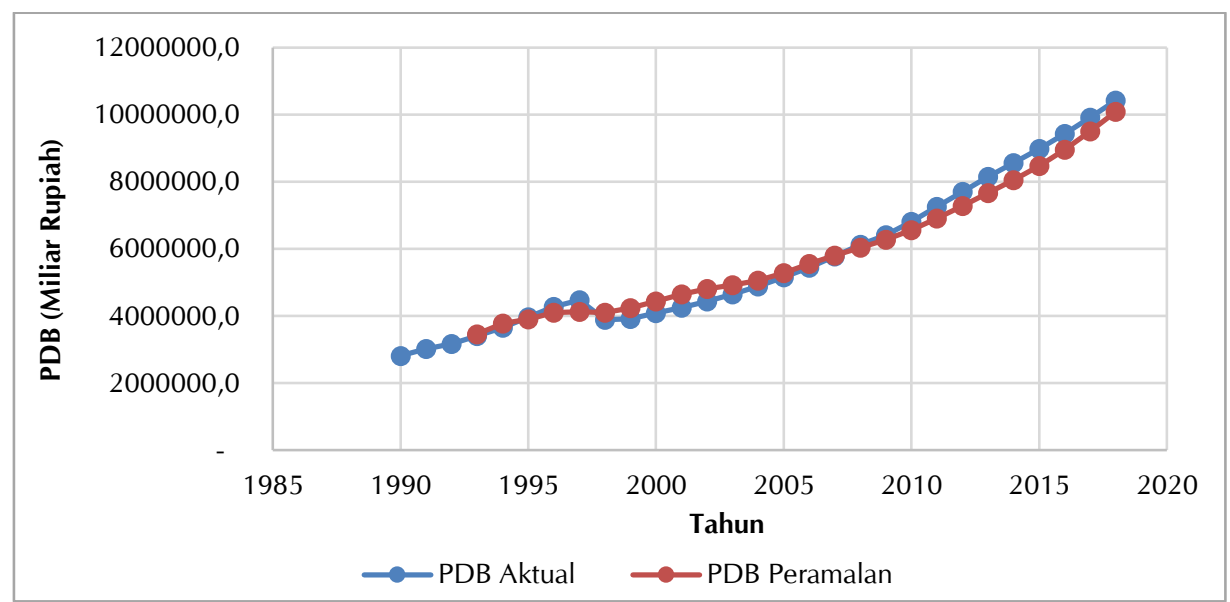

Gambar 8. Perbandingan nilai aktual dan peramalan model VAR untuk PDB 
5. Interpretasi Model VECM

Model VECM pada Persamaan 9 menjelaskan bahwa ekspor batubara (DLNEB) dan konsumsi batubara (DLNKB) memberikan dampak positif terhadap PDB (DLNPDB). Nilai DLNPDB merupakan nilai rata-rata yang diestimasi (nilai ratarata kondisional). Besaran pengaruh ekspor batubara dan konsumsi batubara untuk estimasi nilai PDB (DLNPDB) adalah sebagai berikut:

1) Nilai $0,398 *$ DLNPDBt -1 dan $0,234 *$ DLNPDBt -2 adalah suatu koefisien yang menggambarkan efek langsung setiap perubahan DLNPDB pada satu dan dua periode sebelumnya sebesar satu satuan terhadap nilai ratarata DLNPDB yang diestimasi. Hal ini diartikan bila terjadi kenaikan satu unit satuan pada variabel PDB (DLNPDB) pada satu dan dua periode sebelumnya dapat memberikan kenaikan pada nilai DLNPDB yang diestimasi sebesar 0,398 dan 0,234 unit satuan.

2) Nilai $\quad 0,009 *$ DLNEB $_{\mathrm{t}-1}$ dan $0,116 *$ DLNEB $_{\mathrm{t}-2}$ adalah suatu koefisien yang menggambarkan efek langsung setiap perubahan DLNEB pada satu dan dua periode sebelumnya sebesar satu satuan terhadap nilai rata-rata DLNPDB yang diestimasi. Hal ini berarti bila terjadi kenaikan satu unit satuan pada variabel ekspor batubara (DLNEB) pada satu dan dua periode sebelumnya dapat memberikan kenaikan nilai PDB (DLNPDB) yang diestimasi sebesar 0,009 dan 0,116 unit satuan.

3) Nilai $0,162 *$ DLNKB $_{\mathrm{t}-1}$ dan $0,033 *$ DLNKB $_{\mathrm{t}-2}$ adalah suatu koefisien yang menggambarkan efek langsung setiap perubahan DLNKB pada satu dan dua periode sebelumnya sebesar satu satuan terhadap nilai rata-rata DLNPDB yang diestimasi. Hal ini berarti bila terjadi kenaikan satu unit satuan pada variabel konsumsi batubara (DLNKB) pada satu dan dua periode sebelumnya dapat memberikan kenaikan pada nilai PDB (DLNPDB) yang diestimasi sebesar 0,162 dan 0,033 unit satuan.

4) Nilai -0,342 pada Persamaan 9 menunjukkan nilai koreksi pengaruh penyimpangan variabel PDB hasil peramalan terhadap variabel PDB aktual. Bila terjadi kenaikan sebesar satu unit satuan pada periode sebelumnya akan mengakibatkan penurunan pada DlnPDB sebesar 0,342 .

Berdasarkan studi empiris menggunakan analisis VAR selama periode 29 tahun yaitu dari 1991 hingga 2018, pengaruh yang diberikan konsumsi batubara dan ekspor batubara terhadap pertumbuhan ekonomi adalah positif.

Ekspor batubara berdampak positif terhadap pertumbuhan ekonomi dikarenakan ekspor batubara masih menjadi sumber penghasil devisa negara. Devisa tersebut dapat digunakan untuk memenuhi permintaan bahan baku dan barang modal dalam negeri yang hanya ada di negara lain. Oleh karena itu jika terjadi penurunan ekspor batubara akan menyebabkan nilai PDB menurun yang pada akhirnya dapat menyebabkan penurunan pertumbuhan ekonomi.

Walaupun ekspor batubara berdampak positif bagi PDB, ekspor batubara Indonesia mengalami penurunan mulai 2015. Penurunan tersebut terjadi dikarenakan masalah yang terkait dengan lingkungan. Seperti yang diketahui bahwa batubara merupakan salah satu sumber penghasil emisi $\mathrm{CO}_{2}$. Lin, Inglesi-Lotz dan Chang (2018) melakukan penelitian di India dan China terkait hubungan antara konsumsi batubara, emisi $\mathrm{CO}_{2}$, dan pertumbuhan ekonomi. Hasilnya menunjukkan bahwa di India dan China, konsumsi batubara dapat meningkatkan emisi $\mathrm{CO}_{2}$ sehingga dapat berdampak negatif pada pertumbuhan ekonomi. Dari penelitian tersebut jelas bahwa dampak penggunaan batubara dapat memberikan pengaruh negatif pada pertumbuhan ekonomi. Cina dan India merupakan negara yang mengimpor batubara dari Indonesia. Mengingat negara-negara tersebut mulai memotong penggunaan batubara dalam negeri karena faktor lingkungan, hal tersebut dapat mengakibatkan penurunan ekspor batubara Indonesia.

Selain masalah lingkungan, pemerintah Indonesia juga telah membuat regulasi terkait pengutamaan mineral dan batubara untuk kepentingan dalam negeri, pengendalian 
ekspor mineral dan batubara yaitu dengan meningkatkan nilai tambah mineral dan batubara yang sudah diatur dalam peraturan UU No. 4 Tahun 2009, PP No. 23 dan Permen ESDM No. 25 Tahun 2018. Hal ini dapat mengakibatkan pengurangan ekspor batubara untuk ke depannya.

Konsumsi batubara dalam negeri pun berdampak positif pada pertumbuhan ekonomi. Hal ini dikarenakan batubara digunakan sebagai salah satu sumber energi. Sebagai contoh pada sektor ketenagalistrikan, batubara dianggap sebagai sumber energi yang murah untuk tenaga listrik. Tidak hanya itu, penggunaan batubara untuk beberapa tahun ke depan diperkirakan akan terus meningkat. Hal ini dikarenakan batubara ini akan digunakan untuk memenuhi kebutuhan energi dalam negeri sebagai modal pembangunan.

\section{KESIMPULAN DAN SARAN}

Dapat disimpulkan bahwa dari studi empiris ini selama periode 29 tahun yaitu dari 1990 hingga 2018, konsumsi batubara dalam negeri dan ekspor batubara berdampak positif terhadap pertumbuhan ekonomi.

Berdasarkan studi empiris menunjukkan bahwa apabila terjadi kenaikan satu unit satuan pada variabel ekspor batubara (DLNEB) pada satu dan dua periode sebelumnya dapat memberikan kenaikan pada nilai PDB (DLNPDB) yang diestimasi sebesar 0,009 dan 0,116 unit satuan atau total kenaikan sebesar 0,125 unit satuan. Selain itu, bila terjadi kenaikan satu unit satuan pada variabel konsumsi batubara (DLNKB) pada satu dan dua periode sebelumnya dapat memberikan kenaikan pada nilai PDB (DLNPDB) yang diestimasi sebesar 0,162 dan 0,033 unit satuan atau total kenaikan sebesar 0,195 unit satuan.

Dikarenakan hasil studi empiris menunjukkan bahwa ekspor dan konsumsi batubara memberikan dampak positif bagi pertumbuhan ekonomi, jika terjadi penurunan ekspor maupun konsumsi dalam negeri dapat mengakibatkan penurunan pertumbuhan ekonomi. Rekomendasi yang dapat diberikan adalah pengurangan ekspor boleh dilakukan dengan tetap meningkatkan penggunaan batubara dalam negeri. Peningkatan tersebut dibarengi dengan meningkatkan efisiensi pemanfaatan batubara melalui teknologi dan pengembangan bahan bakar alternatif serta secara perlahan beralih ke energi terbarukan.

\section{UCAPAN TERIMA KASIH}

Ucapan terima kasih penulis ucapkan kepada instansi Badan Pusat Statistik Pusat yang telah membantu memberikan data untuk penelitian ini.

\section{DAFTAR PUSTAKA}

Arianti, J., Siahaan, R. L. dan Sihaloho, L. (2017) "Pengaruh ekspor minyak kelapa sawit/crude palm oil (CPO) terhadap pertumbuhan ekonomi di Indonesia pasca reformasi (19982015)," in Profesionalisme Akuntan Menuju Sustainable Business Practice. Bandung: SNAB Universitas Widyatama, hal. 329-333.

Badan Pusat Statistik (2015) Produk domestik bruto atas dasar harga konstan 2000 menurut lapangan usaha (miliar rupiah), 2000-2014, www.bps.go.id. Tersedia pada:

https://www.bps.go.id/statictable/2009/07/02 /1200/-seri-2000-pdb-atas-dasar-hargakonstan-2000-menurut-lapangan-usahamiliar-rupiah-2000-2014.html (Diakses: 12 Oktober 2018).

Badan Pusat Statistik (2020) PDB triwulanan atas dasar harga konstan 2010 menurut lapangan usaha (miliar rupiah), 2014-2020, www.bps.go.id. Tersedia pada:

https://www.bps.go.id/linkTableDinamis/vie w/id/827 (Diakses: 20 April 2020).

Chang, T., Deale, D., Gupta, R., Hefer, R., InglesiLotz, R. dan Simo-Kengne, B. (2017) "The causal relationship between coal consumption and economic growth in the BRICS countries: Evidence from panel-Granger causality tests," Energy Sources, Part B: Economics, Planning, and Policy, 12(2), hal. 138-146. doi: 10.1080/15567249.2014.912696.

Dewi, M. P. (2018) Analisis ekspor batubara di Indonesia. Universitas Islam Indonesia.

Direktorat Sumber Daya Energi Mineral dan Pertambangan BAPPENAS (2016) Kajian ketercapaian target DMO batubara sebesar $60 \%$ produksi nasional pada tahun 2019. Jakarta: BAPPENAS. Tersedia pada: 
https://www.bappenas.go.id/files/5415/0898/ 5954/Laporan_Akhir_Kajian_DMO_Batubara _Final.pdf.

Faisal, F., Tursoy, T. dan Ercantan, O. (2017) "The relationship between energy consumption and economic growth: Evidence from nonGranger causality test," Procedia Computer Science, 120, hal. 671-675.

doi: 10.1016/j.procs.2017.11.294

Ginting, A. M. (2017) "Analisis pengaruh ekspor terhadap pertumbuhan ekonomi Indonesia," Buletin Ilmiah Litbang Perdagangan, 11(1), hal. 1-20. doi: 10.30908/bilp.v11i1.185.

Haryadi, H. dan Suciyanti, M. (2018) "Analisis perkiraan kebutuhan batubara untuk industri domestik tahun 2020-2035 dalam mendukung kebijakan domestik market obligation dan kebijakan energi nasional," Jurnal Teknologi Mineral dan Batubara, 14(1), hal. 59. doi: 10.30556/jtmb.Vol14.No1.2018.192.

Juanda, B. dan Junaidi (2012) Ekonometrika deret waktu: Teori dan aplikasi. Bogor: IPB Press.

Kementerian Energi dan Sumber Daya Mineral (2016) Handbook of energy and economic statistics of Indonesia 2016. Final. Jakarta: Kementerian Energi dan Sumber Daya Mineral.

Kementerian Energi dan Sumber Daya Mineral (2018) Handbook of energy and economic statistick of Indonesia 2018. Final. Jakarta: Kementerian Energi dan Sumber Daya Mineral.

Kim, H.-M. dan Yoo, S.-H. (2016) "Coal consumption and economic growth in Indonesia," Energy Sources, Part B: Economics, Planning, and Policy, 11(6), hal. 547-552. doi: 10.1080/15567249.2012.690503.

Korra, M. (2017) Kajian dampak konsumsi energi terhadap pertumbuhan ekonomi di Indonesia: Analisis kausalitas dan peramalan. Institut Teknologi Bandung.
Li, J. dan Li, Z. (2011) "A causality analysis of coal consumption and economic growth for China and India," Natural Resources, 02(01), hal. 54-60. doi: 10.4236/nr.2011.21007.

Lin, F.-L., Inglesi-Lotz, R. dan Chang, T. (2018) "Revisit coal consumption, CO2 emissions and economic growth nexus in China and India using a newly developed bootstrap ARDL bound test," Energy Exploration \& Exploitation, 36(3), hal. 450-463. doi: 10.1177/0144598717741031.

Putra, M. U. M. dan Damanik, S. (2017) "Pengaruh ekspor MIGAS dan non MIGAS terhadap posisi cadangan devisa Indonesia," Jurnal Wira Ekonomi Mikroskil, 7(2), hal. 245-254.

Sinaga, R., Rochaid, E. dan Ulfah, Y. (2013) "Pengaruh investasi PMDN, PMA, dan tenaga kerja terhadap ekspor: Sektor pertambangan dan pertumbuhan ekonomi di Kalimantan Timur," Jurnal Eksekutif, 10(2), hal. 312-328.

Sugiyono (2015) Metode penelitian kuantitatif, kualitatif dan R\&D. Bandung: Alfabeta.

Sukirno, S. (2008) Makro ekonomi: Teori pengantar. Jakarta: Raja Grafindo Persada.

Widarjono, A. (2018) Ekonometrika: Pengantar dan aplikasinya disertai panduan eviews. 5 ed. Yogyakarta: UPP STIM YKPN.

Yoo, S.-H. (2006) "Causal relationship between coal consumption and economic growth in Korea," Applied Energy, 83(11), hal. 11811189. doi: 10.1016/j.apenergy.2006.01.010.

Yudiartono, Anindhita, Sugiyono, A., Wahid, L. M. A. dan Adiarso (ed.) (2018) Outlook energi Indonesia: Energi berkelanjutan untuk transportasi darat. Jakarta: PPIPE dan BPPT.

Zahmir, A.-Q. (2014) Hubungan kuasalitas antara konsumsi energi dengan pertumbuhan ekonomi Indonesia. Universitas Syiah Kuala Darussalam. 